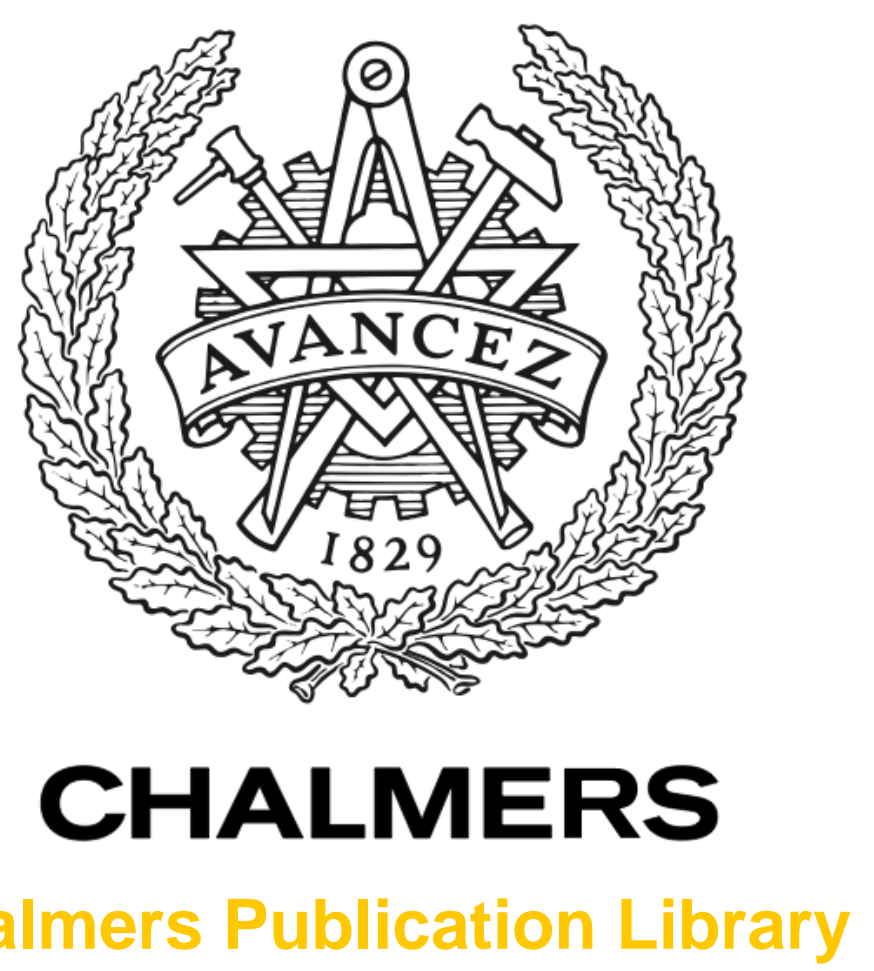

\title{
DYNAMICS OF IN-FURNACE PROCESSES IN A CFB BOILER
}

This document has been downloaded from Chalmers Publication Library (CPL). It is the author's version of a work that was accepted for publication in:

\section{Proceedings of the 8th International Conference on Circulating Fluidized Beds}

Citation for the published paper:

Johansson, A. ; Song, B. ; Johnsson, F. et al. (2005) "DYNAMICS OF IN-FURNACE

PROCESSES IN A CFB BOILER". Proceedings of the 8th International Conference on

Circulating Fluidized Beds pp. 159-166.

Downloaded from: http://publications.lib.chalmers.se/publication/237921

Notice: Changes introduced as a result of publishing processes such as copy-editing and formatting may not be reflected in this document. For a definitive version of this work, please refer to the published source. Please note that access to the published version might require a subscription. 


\section{Circulating Fluidized Bed Techmology VIII}

Proceedings of the 8th International Conference on Circulating Fluidized Beds

Hangzhou, China, May 10-13, 2005

Edited by

Kefa Cen

College of Mechanical and Energy Engineering

Zhejiang University

International Academic Publishers

World Publishing Corporation 


\title{
DYNAMICS OF IN-FURNACE PROCESSES IN A CFB BOILER
}

\author{
Andreas Johansson ${ }^{1,2}$, ByungHo Song ${ }^{3}$, Filip Johnsson ${ }^{1}$, Lars-Erik Åmand', \\ Bo Leckner ${ }^{1}$ \\ ${ }^{1}$ Department of Energy Conversion, Chalmers University of Technology \\ SE-412 96 Göteborg, Sweden \\ ${ }^{2}$ University College of Borås, SE-501 90 Borås, Sweden \\ ${ }^{3}$ Department of Chemical Engineering, Kunsan National University, Kunsan, Jeonbulk, \\ 573-701, Korea
}

\begin{abstract}
With the aim of understanding the dynamics of combustion, this work examines simultaneous fluctuations in fluid dynamic parameters and gas composition in a CFB furnace operated with coal as a fuel. Fluid dynamic parameters are pressure and air flow to the furnace. Gas composition was obtained by a zirconia-cell probe and a gas suction probe connected to a mass spectrometer having a high time resolution $(10 \mathrm{~Hz})$. The fluctuations of interest are around $1 \mathrm{~Hz}$ and below $0.3 \mathrm{~Hz}$. The fluctuations below $0.3 \mathrm{~Hz}$, which have not been investigated previously, are found to originate from irregularities in the fuel feed. These irregularities give rise to periods of reducing conditions because high inputs of fuel yield an increased pressure in the furnace and a decreased air feed to the furnace, which then occurs concurrent with the release of a high amount of volatiles. There is also a correlation between reducing conditions and the concentration of hydrocarbons.
\end{abstract}

\section{Introduction}

Especially during combustion of fuel with a significant content of volatiles, such as brown coal, biofuels and waste, one has to make an effort to achieve an even fuel distribution over time and over cross-section in order to avoid variations in gas concentration. This may be difficult, since these fuels dry and devolatilize rapidly compared to their dispersion in a fluidized bed. It has been reported that large fluctuations between a reducing and an oxidizing environment are present in fluidized bed furnaces during operation with high-volatile fuels (e.g. Niklasson et al., 2003). Such unmixedness leads to fluctuations in gas composition and retards conversion of gaseous fuel components to downstream regions of the combustion chamber, which might influence burn-up and cause undesirable emissions.

To optimize the performance of fluidized bed boilers and to develop combustion models it is necessary to better understand the origin of the changes between reducing and oxidizing conditions. This requires information on the link between the fluid dynamics and the combustion process, which has not been sufficiently investigated. This work takes a first step to establish such a link by simultaneous measurements of fluid dynamics and gas concentrations in a CFB boiler. The parameters measured include fluctuations in pressure at various locations in the furnace and in the air-plenum, and the air flow in various positions in the air-feed system together with gas concentrations. In addition, variations in fuel feed were measured. The work discusses the fluctuations and interactions between the measured parameters. 


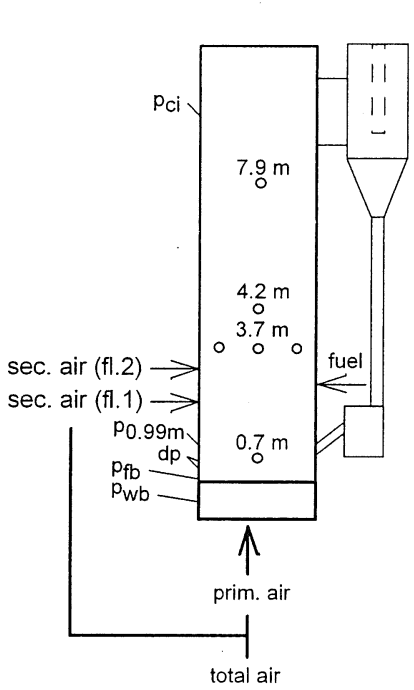

- with bottom bed

- without bottom bed
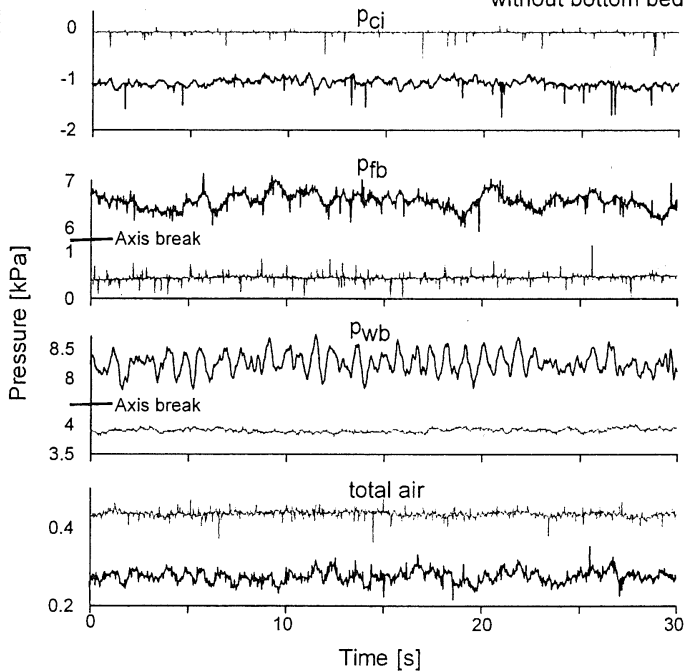

Figure 1. Measurement position in the $12 \mathrm{MW}_{\text {th }} \mathrm{CFB}$ boiler and pressure signals from different locations in the boiler during operation with- and without a bottom bed (see Table 1 for operating conditions).

\section{Experiments}

Figure 1 shows the measurement positions in the $12 \mathrm{MW}_{\text {th }}$ CFB boiler used in this work. The furnace has a cross-section of $1.7 \times 1.4 \mathrm{~m}$ and a height of $13 \mathrm{~m}$. It is further described elsewhere (Leckner et al., 1991). The boiler was operated with coal at the loads listed in Table 1. The cases investigated cover variations in load and total pressure drop over the furnace. If not otherwise stated the reference case is the basis for the results shown. Pressure fluctuations were measured against atmosphere through wallmounted pressure taps in four positions: in the windbox, just above the air nozzles, at 1 $\mathrm{m}$ above the nozzles and close to the inlet of the cyclone. Simultaneously, the primary, secondary, and total air flows were measured by venturi meters together with the oxygen concentration in the flue gas duct and the signals from the probes situated in the furnace. The latter include measurements with zirconia-cell probes and a gas suctionprobe connected to a mass spectrometer. The zirconia-cell probe indicates whether the environment in the furnace is oxidizing or reducing (peaks in the signal of the zirconia cell represent reducing conditions), as previously described by Lyngfelt et al. (1993). The furnace measurements were mainly performed in the center of the furnace at three heights, $0.67,3.7$ and $7.9 \mathrm{~m}$ above the air nozzles, whereas correlation measurements between two probes (zirconia cell and gas suction or two zirconia cells) were only performed at $3.7 \mathrm{~m}$ above the air nozzles. In the latter case, the probes were inserted so that the tips were located in the centre of the furnace. These measurements were repeated with the probes withdrawn so that the distance between the tips was $100 \mathrm{~mm}$. 
Table 1. Operating conditions.

\begin{tabular}{|c|c|c|c|c|c|c|}
\hline Case & $\begin{array}{c}\text { Boiler } \\
\text { load } \\
{[\mathrm{MW}]}\end{array}$ & $\begin{array}{c}\text { Pr. drop } \\
\text { furnace } \\
{[\mathrm{kPa}]}\end{array}$ & $\begin{array}{c}\text { Pr. drop } \\
\text { nozzles } \\
{[\mathrm{kPa}]}\end{array}$ & $\begin{array}{c}\text { Prim/Tot } \\
\text { air ratio } \\
{[-]}\end{array}$ & $\begin{array}{c}\text { Bed } \\
\text { temp } \\
{\left[{ }^{\circ} \mathrm{C}\right]}\end{array}$ & $\begin{array}{c}\text { Particle } \\
\text { size } \\
{[\mathrm{mm}]}\end{array}$ \\
\hline Reference case & 6 & 7.5 & 1.7 & 0.6 & 850 & 0.3 \\
\hline Low mass content & 7.5 & 2.0 & 3.5 & 0.6 & 890 & $<0.3^{*}$ \\
\hline High load & 7.5 & 7.5 & 3.1 & 0.6 & 850 & 0.3 \\
\hline
\end{tabular}

*limestone added in this case

The mass spectrometer connected to the gas suction probe is originally designed to measure constituents of exhaust gas in real time (automotive industry). Its performance is reported elsewhere (Dearth, 1999). Although the mass spectrometer allows on-line time resolved quantification of different gas compounds, in the present tests it was calibrated to measure only one gas component at the time to increase time resolution (benzene is reported here). This made it possible to record fluctuations in gas composition with a resolution of $10 \mathrm{~Hz}$. To prevent air leakage during the probe measurements, a piece of wet cloth was applied around the probe in the measurement port. The fuel feed rate was studied under cold conditions. The fuel then by-passed the furnace, close to the position where a conveyer discharges the fuel into the furnace, and was redirected into a container resting on a scale. Variations in fuel feed rate with time was obtained from the increase in container weight with time. The fuel conveyer near the inlet into the furnace contains densely spaced scrapes, which transport the fuel from the outlet of the fuel hoppers to the fuel feed chute, where the fuel particles are blown into the furnace in order to improve the dispersion. At the inlet to the fuel feed chute there is a cell feeder, which distributes the fuel into the chute. At normal load the time between the discharge of scrapes is around one second. The cell feeder, consisting of 4 cells and rotating with 36 revolutions per minute, distributes the fuel of each scrape into the chute before the discharging of the following scrape. The bottoms of the fuel hoppers are located below the fuel inlet and the conveyer is inclined by around $40^{\circ}$.

\section{Results and Discussion}

Figure 1 presents typical time sequences of pressure in the windbox (wb), in the bottom of the furnace (fb) and in the cyclone inlet (ci) for two operation conditions, the reference case and the case with a low mass content (i.e. without a bottom bed). In the reference case with a bottom bed present there is, as expected, considerable fluctuations, not only in the bed pressure but also in the flow and in the pressure in the air-plenum and at the top of the furnace. Without a bottom bed all signals show low fluctuations. The fluctuations in the presence of a bottom bed yield frequency spectra with energies concentrated around $1 \mathrm{~Hz}$ and below $0.3 \mathrm{~Hz}$. The latter frequency was roughly observed in all signals and at all loads, also in the case without a bottom bed.

A frequency spectrum with a peak around $1 \mathrm{~Hz}$ has previously been observed in the same boiler. It is caused by the bubble passage through the bottom bed (Johnsson et al., 1997). The fluctuation below $0.3 \mathrm{~Hz}$, on the other hand, has not been investigated before. Such low frequency fluctuations have been regarded as variations in operating conditions but not associated with any relevant process taking place in the furnace. The low-frequency fluctuations can be suspected to be due to variations in the fuel feed, i.e. 
Table 2. Variations in fuel feed rate and corresponding frequencies as measured during cold conditions. Fuel feed rate is related to the average fuel feed rate, $\bar{F}_{F}$.

\begin{tabular}{|c|c|c|c|c|}
\hline Level of fuel feed rate & $\geq 2 \times \bar{F}_{F}$ & $\geq 4 \times \bar{F}_{F}$ & $\geq 6 \times \bar{F}_{F}$ & $\geq 8 \times \bar{F}_{F}$ \\
\hline No of events. [-] & 158 & 61 & 25 & 7 \\
\hline Frequency [Hz] & 0.44 & 0.17 & 0.07 & 0.02 \\
\hline
\end{tabular}

to variations in the operating conditions. However, these variations are strongly linked to the fluid dynamics and the progress of combustion. In Figure 2, time series of the fuel feed from the conveyor together with its average value is shown. Large fluctuations are present in the fuel feed rate, including a period of $8 \mathrm{~s}$ without any fuel input and a period with a fuel feed rate of more than ten times as high as the average value. The periods of high feed rates occur at low frequencies, and as given by Table 2 , where the peaks in fuel feed rate are counted, the higher the fuel feed the lower the frequency of the peaks. The variation in fuel feed is due to the escape of small fuel particles from the scrapes through the gap between the scrapes and the wall of the conveyer. These particles are then caught by other scrapes, where this gap is smaller (variations were observed) or sealed by larger particles. The irregularities in the fuel feed yield variations in the gas production in the furnace, since drying and devolatilization occur rapidly. This affects the furnace pressure, which varies with gas production. The link between a high input of fuel (high release of volatiles) and a high pressure in the bottom of the furnace gives a significant correlation between the signal of the zirconia cell and the furnace pressure, where reducing conditions are interpreted as a measure of high release of volatiles. This relationship is seen in Figure 3, which shows time sequences of the pressure in the furnace bottom and the signal of a zirconia cell obtained at the 7.9 $\mathrm{m}$ level. In order to better visualize the correlation in Figure 3, the pressure signal was filtered and then made into a binary signal $\hat{p}$, applying

$$
\hat{p}=0.5 *\left\{\frac{p(t)-p^{\prime}}{\left|p(t)-p^{\prime}\right|}+1\right\}
$$

where $p^{\prime}$ is the value above which the pressure is labeled as high and $p(t)$ is the filtered

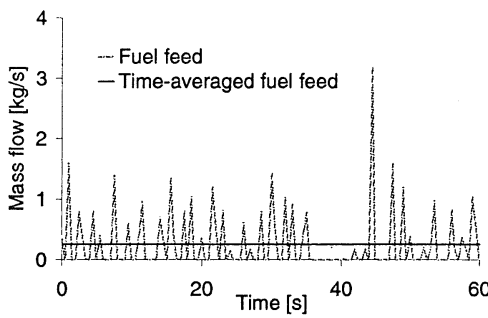

Figure 2. Variations in the fuel feed.

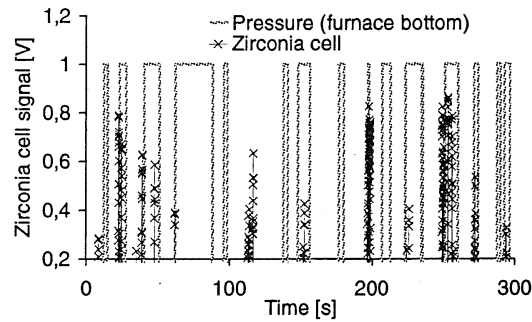

Figure 3. Time series of the zirconia cell signal at $7.9 \mathrm{~m}$ and the digitalized pressure at $0.0 \mathrm{~m}$ in the furnace. 

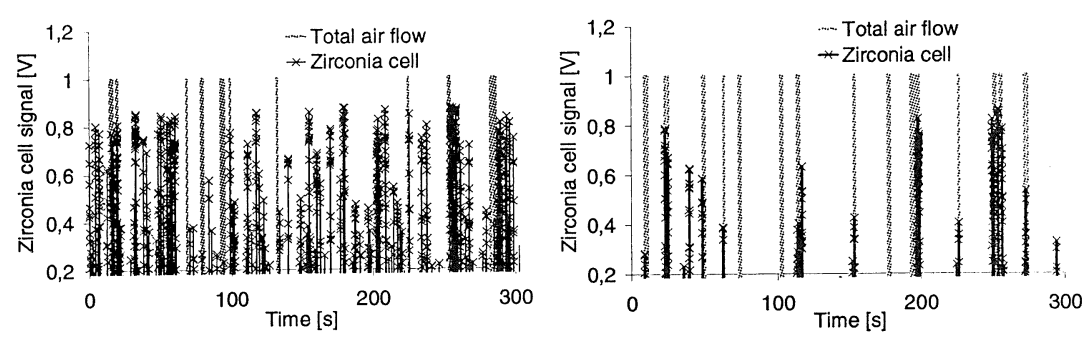

Figure 4. Time series of the zirconia cell signal and total air flow in the reference case at two heights. (a) $3.7 \mathrm{~m}$, time fraction of reducing conditions is 0.099 . (b) $7.9 \mathrm{~m}$, time fraction of reducing conditions is 0.012 .

pressure signal (using a moving average of $3 \mathrm{~s}$ ). It can be seen that the increased pressure in the bottom of the furnace often coincides with reducing conditions, even though the zirconia-cell probe only measures in one position and thereby gives an incomplete picture of the gas composition over the cross section. The reason for the smaller number of occasions of reducing conditions than the number of pressure peaks is probably that some of the reducing regions eventually mix with air as they pass through the furnace. There are considerably more reducing conditions in the lower position $(3.7 \mathrm{~m})$ as can be seen in Figure $4 \mathrm{a}$. Figure 4 also shows the correlation between the zirconia cell and the air flow entering the furnace. Also the signal of the air flow is filtered and made binary, applying Equation (1) with $p^{\prime}$ as the value below which the air flow is labeled as low (i.e. a peak in $\hat{p}$ corresponds here to a dip in the air feed). The correlation is poor in the lower position (Figure 4a) but much better in the upper position (Figure $4 \mathrm{~b}$ ), where almost all reducing conditions occur simultaneously with low air feed. The lack of correlation in Figure 4a, is most likely because in the lower position conditions are also reducing due to maldistribution of fuel or air over the cross section of the bed. It can be concluded that most such reducing regions mix with air before reaching the $7.9 \mathrm{~m}$ level, leaving only those originating from high fuel input. Hence, occasionally high fuel inputs (cf. Figure 2) increase the furnace pressure and

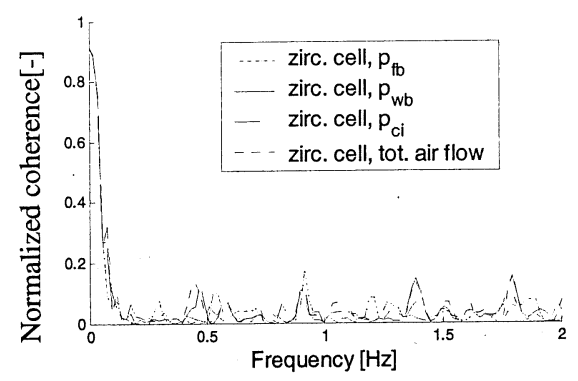

Figure 5. Coherence between the zirconia cell and various pressures and the total air flow in the reference case. The zirconia cell probe was applied at $\mathrm{h}=3.7 \mathrm{~m}$.

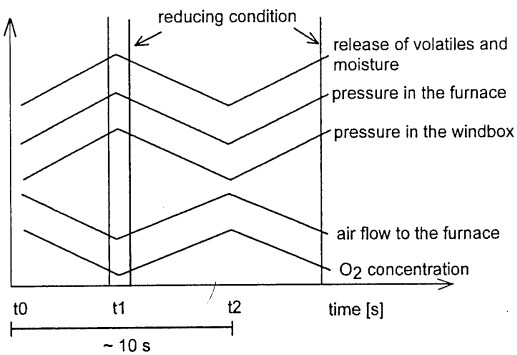

Figure 6. Artificial time series showing the effects of the low frequency fluctuations. 


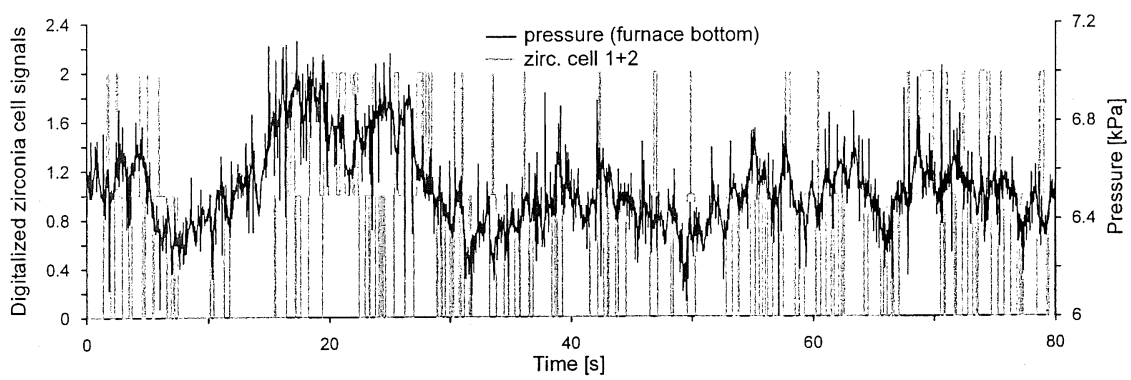

Figure 7. Time series of two simultaneously applied zirconia cell probes during the reference load. The distance between the probe tips were $1 \mathrm{~m}(\mathrm{~h}=3.7 \mathrm{~m})$.

thereby reduce the air feed (assuming a constant fan power). It was also found that the presence of reducing conditions at $7.9 \mathrm{~m}$ coincides with high pressure in the windbox and low oxygen concentration in the back pass. In addition, Figure 5 shows normalized coherence between the signal of a zirconia cell, pressure, and the air flow. There is a high coherence for low frequencies (cf. Table 2), which confirms the connection between reducing conditions, high furnace pressure and a low air feed. Similar relationships were found at all loads investigated.

The course of events caused by the irregular fuel feed is schematically summarized in Figure 6, illustrating a correlation between the pressures in the furnace and in the windbox, as well as between the air flow entering the furnace and the oxygen concentration. The pressure in the furnace, and consequently the pressure in the windbox, follows the release of volatiles and moisture. An increased pressure due to release of volatiles from an increase in fuel feed rate reduces the air flow into the furnace and, as a result, the conditions become reducing and the oxygen concentration in the back pass decreases. The irregularities in the fuel feed are, of course, an effect of the design of the conveyer. However, similar low frequency fluctuations and similar links beteen pressure and air feed are seen in other boilers as well (e.g. the $235 \mathrm{MW}_{\mathrm{e}}$ boiler in Bogatynia, Poland).

Figure 7 shows time series of simultaneous measurements with two zirconia-cell probes together with pressure in the bottom of the furnace. The signals are made binary in accordance with Equation (1) and then added (the vertical axis indicates the number of zirconia cells $(0,1$ or 2$)$ which register reducing condition). The probes were inserted at $3.7 \mathrm{~m}$ height, so that the tips were separated by $1 \mathrm{~m}$. Reducing conditions were often registered at the same time by both cells, which imply that these reducing conditions are of considerable lateral extension and rather global as the width of the furnace is $1.4 \mathrm{~m}$. Such reducing conditions could not be due to a maldistribution of fuel over the cross section (as a maldistribution that covers most of the cross section is no maldistribution). They are instead caused by the irregularities in the fuel feed as discussed above. Figure 7 also shows that the pressure in the bottom of the furnace is high when globally reducing conditions are detected, whereas it is low when the environment is oxidizing or when only local reducing conditions are present. This confirms that variations in the release of volatiles are connected to fluctuations in the pressure. 


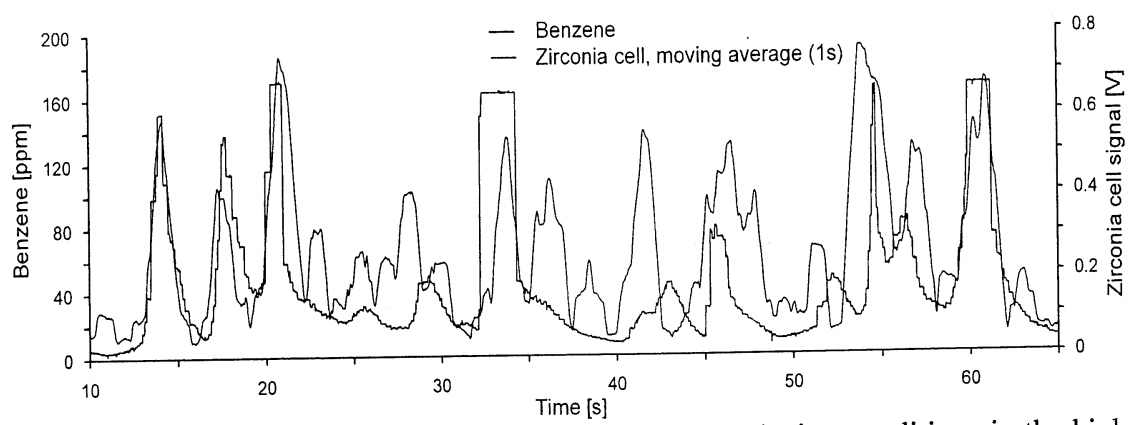

Figure 8. Time series of concentration of benzene and reducing conditions in the high load case $(h=3.7 \mathrm{~m})$.

The reducing conditions are accompanied by high amount of gas compounds typically found during pyrolysis, e.g. carbon monoxide and hydrocarbons. The coexistence of such compounds and reducing conditions was observed simultaneously by the mass spectrometer and the zirconia cell, as exemplified in Figure 8 where the zirconia cell signal is filtered with a moving average to make the character of the signal more analogous to the signal from the mass spectrometer. The agreement between reducing conditions measured by the zirconia cell and benzene measured by the mass spectrometer supports the validity of both measurement methods.

\section{Conclusions}

The interaction between fluctuations in fluid dynamic parameters and gas composition was investigated in a coal-fired CFB boiler. The signals studied show two dominant frequency regions of fluctuations, around $1 \mathrm{~Hz}$ and below $0.3 \mathrm{~Hz}$. The former are related to bubbles, as shown earlier, and the latter spectra are due to variations in the fuel feed, which affect the gas production in the furnace and thereby also the pressure. The fluctuations in pressure lead to variations in the air feed, and as a result, a low air feed rate occurs simultaneously with a high release of volatiles. This yields reducing conditions of considerable magnitude and duration, which requires excess air to prevent unburned fuel from escaping the boiler. By lowering the variations in fuel feed it should be possible to lower the air to fuel ratio as well.

\section{Acknowledgement}

This work is financed in part by the Swedish Energy Agency and the research programme: Advanced CFB for clean and efficient coal power (CLEFCO) of the research fund for Coal and Steel. The assistance of the people operating the $12 \mathrm{MW}$ CFB boiler at Chalmers University of Technology is also acknowledged. 


\section{References}

Dearth, M.A. "Evaluation of a commercial mass spectrometer for its potential to measure auto exhaust constituents in real time", Ind. Eng. Chem. Res., 38, 2203-2209(1999).

Johnsson, F., R.C. Zijerveld, and B. Leckner, "Air-plenum pressure fluctuations in a circulating fluidized bed boiler", in Proc. $2^{\text {nd }}$ European Conference on Fluidization, Bilbao, (1997), pp. 223-230.

Leckner, B., M. Golriz, W. Zhang, B-Å. Andersson, and F. Johnsson in Proc. 11th Int. Conf. on Fluidized Bed Combustion, E. J. Anthony Ed., ASME, New York, (1991), pp. 771-776.

Lyngfelt, A., K. Bergqvist, F. Johnsson, L.-E. Åmand, and B. Leckner, "Dependence of sulfur capture performance on air staging in a 12 MW circulating fluidized bed boiler", in: Gas cleaning at high temperatures, 1993, Clift, R., Seville, J. P. K. (Eds.), Blackie, Glasgow, (1993), pp. 470-491.

Niklasson, F., F. Johnsson, and B. Leckner, "Local air ratio measured by zirconia cell in a circulating fluidised bed furnace", Chem. Eng. J., 96, 145-155 (2003).

van Ommen, J., R.J. van der Schaaf, J.C. Schouten, B.G.M. van Wachem, M.-O. Coppens, and C. M. van der Bleek, "Optimal placement of probes for dynamic pressure measurements in large-scale fluidized beds", Powder Technology, 139, 264-276 (2004). 